\title{
Collagenous Gastritis: A Case Report, Morphologic Evaluation, and Review
}

\author{
Z. Vesoulis, M.D., Gerard Lozanski, M.D., Pars Ravichandran, M.D., Edward Esber, M.D. \\ Departments of Pathology (ZV, GL, PR) and Gastroenterology (EE), Summa Health Systems, Akron, Ohio
}

Collagenous gastritis is rare; there are only four previous case reports. Histologic features seem to overlap with the other "collagenous enterocolitides"; however, pathologic criteria are not yet established for the diagnosis of collagenous gastritis. We describe an additional case of ostensible collagenous gastritis in a patient who initially presented with celiac sprue and subsequently developed colonic manifestations of mucosal ulcerative colitis. Endoscopic biopsies of the stomach revealed deposition of patchy, very thick bandlike subepithelial collagen in gastric antral mucosa, focal superficial epithelial degeneration, numerous intraepithelial lymphocytes, and a dense lamina propria lymphoplasmacytic infiltrate. Image analysis evaluation of gastric antral biopsies demonstrated a mean thickness of subepithelial collagen of $27.07 \mu$. Morphologic comparison was made with age-matched control groups of 10 patients who had normal gastric mucosal biopsies and 10 patients who had "chronic" gastritis, which revealed mean subepithelial collagen measures of $1.37 \mu$ and $1.19 \mu$, respectively. We compared these morphologic findings with those of all previous case reports of collagenous gastritis and propose a pathologic definition based on the limited combined data. It seems that subepithelial collagen is dramatically thickened in reported cases of collagenous gastritis, with a cumulative mean measure of $36.9 \mu$. It is also apparent from this and previous reports that the thickened subepithelial collagen is accompanied by a chronic or chronic active gastritis and sometimes intraepithelial lymphocytes and surface epithelial damage. Recently described associations of lymphocytic gastritis, sprue, and lymphocytic colitis as well as collagenous and lymphocytic colitis suggest a common pathogenesis that empirically may include collagenous gastritis in the same disease spectrum. We propose that collagenous gastritis can be confi-

Copyright (C) 2000 by The United States and Canadian Academy of Pathology, Inc.

VOL. 13, NO. 5, P. 591, 2000 Printed in the U.S.A

Date of acceptance: November 2, 1999.

Address reprint requests to: Dr. Vesoulis, Department of Pathology,

Summa Health Systems, 525 E. Market Street, Akron, OH 44304. dently identified by using analogous defined features of collagenous colitis: subepithelial collagen more than $10 \mu$ in a patchy distribution, lamina propria lymphoplasmacytic infiltrates, intraepithelial lymphocytes, and surface epithelial damage. Collagenous gastritis also seems to have the same spectrum of associated clinical findings as collagenous colitis, including frequent coexistence of celiac sprue, watery diarrhea syndrome, and female predominance.

KEY WORDS: Celiac sprue, Collagenous colitis, Collagenous gastritis, Lymphocytic colitis, Lymphocytic gastritis, Mucosal ulcerative colitis.

Mod Pathol 2000;13(5):591-596

Collagenous colitis, first described by Lindstrom in 1976 (1), is an inflammatory bowel lesion; diagnosis requires the clinical presentation of chronic watery diarrhea, an endoscopically normal or "near normal" mucosa and colon biopsy with subepithelial collagen deposition, chronic inflammation, and epithelial degeneration. Collagenous colitis is probably an autoimmune disorder (2-6), although recently other potential causes have been proposed and include bacterial toxins, cytotoxins, nonsteroidal anti-inflammatory drugs, infectious agents, and antibiotics (7-10).

"Collagenous" sprue was originally described as a variant of typical sprue with villous atrophy, prominent subepithelial collagen deposition, and refractoriness to a gluten-free diet (11). Some degree of collagen deposition in sprue may be a common and relatively nonspecific finding that occurs without alteration of the typical clinical course (12).

Collagen deposition in gastric mucosa has rarely been described; there are four case reports to date, and no detailed pathologic descriptions or diagnostic criteria have been elucidated (13-16). We describe a case of collagenous gastritis that developed in association with celiac disease and ulcerative colitis. Careful morphometric comparison of this case and control groups of normal gastric antral biopsies and "chronic gastritis" cases illustrates the striking and overt subepithelial collagen deposition that delineates this unusual lesion. We also review 
and compare the clinical and pathologic features of other reported cases of collagenous gastritis and attempt to derive unifying features and histopathologic criteria that characterize this lesion. The relationship and frequent co-occurrence of collagenous gastritis, collagenous and lymphocytic colitis, and sprue is also examined.

\section{CASE REPORT}

A 57-year-old Caucasian man presented with a hypochromic, microcytic anemia and loose stools for several months. He experienced a $5 \mathrm{lb}$ weight loss and denied abdominal pain. His medical history was remarkable for coronary artery disease and lower extremity vascular surgery. There was no history of food allergies, arthritis, or autoimmune disease. His initial workup included an unremarkable colonoscopy, but 4 months later, after persistence of loose stools, continued weight loss, and anemia, an upper gastrointestinal and small bowel series demonstrated small bowel dilation. Repeat esophagogastric duodenoscopy (EGD) with biopsy of the small intestine revealed a severe mucosal villous abnormality. Antigliadin IgG and IgA was elevated $(>15$ EIA units) and antiendomysial IgA was elevated $(>1: 5)$. The patient was treated with a glutenfree diet; symptoms resolved, but intermittent flares of diarrhea continued. Strict adherence to a gluten-free diet was considered questionable for this patient. Repeat upper endoscopy with biopsies revealed a persistent mild villous abnormality without significant collagen deposition. The patient was not rechallenged with gluten. Another colonoscopy was performed after the patient once again presented with diarrhea. Stool cultures were negative for bacterial infection, ova, and parasites, and $C$. difficile toxin assays were negative. Colon biopsy revealed a "nonspecific" increase in the inflammatory content of the lamina propria. The patient continued to have intermittent bouts of moderate diarrhea and eventually developed bloody diarrhea. Colonoscopy performed at this time revealed marked erythema with granularity and ulceration of the entire colon. Biopsies were taken from proximal, transverse, and distal colon and rectum. Perinuclear antineutrophilic cytoplasmic antibody (pANCA) was positive $(>1: 160)$, and cytoplasmic antineutrophilic cytoplasmic antibody (cANCA) was negative $(<1: 20)$. Serum IgA was elevated at $682 \mathrm{mg} / \mathrm{dL}$ (range, 89 to $446 \mathrm{mg} / \mathrm{dl}$ ). and IgG, IgM, complement C3, C4, antinuclear antibody, antithyroglobulin, and antimicrosomal antibodies were negative.

The patient was started on Prednisone and Asacol, and his symptoms markedly improved. Three months after therapy with these drugs and strict emphasis on maintaining a gluten-free diet, his diarrhea and hematochezia resolved. Antigliadin and antiendomysial antibodies were negative in follow-up studies.

\section{MATERIALS AND METHODS}

Five endoscopic biopsies from the stomach, 6 biopsies from the small intestine, and 15 biopsies from the colon were received in $10 \%$ buffered formalin and processed for histologic evaluation in the typical manner. All sections were stained with hematoxylin and eosin, and sections of the stomach were additionally stained with Masson's trichrome, Giemsa, and Warthin-Starry silver stains. Immunohistochemical staining with a selected panel of antibodies, including CD3, UCHL-1(CD45ro), L-26 (CD20), and $\kappa$ and $\lambda$, were performed on all biopsies. Immunostaining incorporated the streptavidin-biotin-peroxidase method after overnight incubation in humidity chambers at $4^{\circ} \mathrm{C}$. A microwave antigen retrieval method was used with all antibodies. Slides were immersed in $200 \mathrm{~mL}$ of APK (Ventana Corp., Tucson, AZ) microwave buffer and heated in an $800 \mathrm{~W}$ microwave oven using a high setting for $5 \mathrm{~min}$. Fifty milliliters of deionized water was added to replace evaporated water from heating, and slides were microwaved for an additional 5 min before automated immunostaining on the Ventana Nexes (Ventana Corp.). Control tissues with established reactivity were stained concomitantly. Morphometric measurements of subepithelial collagen in the hematoxylin and eosin and trichrome sections of the stomach were performed on the CAS 200 image analyzer (Becton-Dickinson, San Jose, CA). Mean measures for each gastric fragment were determined by two independent observers (GL and PR) using Ocular Micrometer v.1 software (Cell Analysis Systems, Elmhurst, IL). Only biopsy fragments with optimal orientation were used in measurements to avoid the artifactual thickening introduced by tangential sections. Each of the five optimally oriented gastric tissue fragments was measured in at least three separate areas representing the thickest visually determined zones of subepithelial collagen. Each measurement consisted of 10 independent readings in each of the three selected zones. Deposition of excessive collagen at each point of measurement was confirmed by comparison with Masson's trichrome stain of parallel sections. Because there is no standard for excessive thickness of subepithelial collagen in gastric biopsies, we compared the test case with the mean range of subepithelial collagen thickness in 10 patients' archival gastric antral biopsies without significant pathologic changes and 10 patients' antral biopsies with chronic gastritis (Table 1). All 
TABLE 1. Computerized Image Analysis Mean Measurements of Gastric Subepithelial Collagen

\begin{tabular}{lcr}
\hline \multicolumn{1}{c}{ Diagnosis } & Range $^{a}$ & Mean $^{a}$ \\
\hline "Normal" gastric antrum $(n=10)^{b}$ & $0.30-2.81 \mu$ & $1.33 \mu$ \\
"Chronic" gastritis $(n=10)^{b}$ & $0.26-2.47 \mu$ & $1.22 \mu$ \\
Collagenous gastritis $(n=1)$ & $13.90-45.00 \mu$ & $24.95 \mu$ \\
\hline
\end{tabular}

${ }^{a}$ Paired $t$ test, two observers. No statistically significant interobserver measurement variability ( $p=.38$ )

${ }^{b}$ Ten patients' gastric biopsies measured in each control group; mean of three biopsy fragments per patient.

control cases were age-matched, and those classified as gastritis included seven cases that originally were diagnosed as chronic nonspecific gastritis, one case of chronic atrophic gastritis with intestinal metaplasia, and two cases of active chronic gastritis with Helicobacter pylori. Studies of the colon have indicated a collagen table thickness with an upper range of 3 to $7 \mu$ as normal $(17,18)$.

\section{RESULTS}

Biopsies of the gastric antrum revealed a diffuse chronic gastritis characterized by predominantly lymphocytic and plasma cell infiltration of superficial and deep mucosa, without lymphoid follicle formation or active inflammation. No organisms that were morphologically compatible with $H$. $p y$ lori were identified on routine hematoxylin and eosin- or Giemsa-stained sections. Subepithelial collagen in the gastric biopsies was thickened in a discontinuous fashion and showed entrapped capillaries. Subepithelial collagen deposition was localized to the superficial epithelium and did not involve the gastric foveolae (Fig. 1). Collagen deposits occupied $63.7 \%$ of the mucosal length of the superficial glandular epithelium of one fragment and $71.1 \%$ of the other involved fragment. Subepithelial collagen deposition, measured by two observers in two gastric mucosal fragments, ranged from 13.9 to
$45.0 \mu$ in thickness with a mean of $24.95 \mu$. Subepithelial collagen was highlighted by Masson's trichrome staining and was negative for amyloid by Congo red and crystal violet stains. Areas containing thickened collagen also had pronounced intraepithelial lymphocytes and focal superficial epithelial cell degeneration with nuclear pyknosis and spongiotic change (Fig. 2).

The thickness of subepithelial collagen in the comparison group of gastric biopsies from 10 patients without abnormality ranged from 0.30 to 2.81 $\mu$ (mean, $1.33 \mu$ ). The thickness of subepithelial collagen in 10 archival cases diagnosed as chronic gastritis ranged from 0.26 to $2.47 \mu$ (mean, $1.22 \mu$ ). A paired $t$ test was performed on both observers' measurements using the data analysis tool of Microsoft Excel. There was no significant difference between the two observers $(P=.38)$ (Table 1).

Lymphocytic infiltrates were distributed within superficial, pit, and glandular epithelium but were most numerous in the superficial zone adjacent to the subepithelial collagen (Fig. 1). Intraepithelial lymphocytes were $\mathrm{T}$ cells as shown by positive staining for CD3 and UCHL-1 and negative staining for CD20 and $\kappa$ and $\lambda$ antibodies. The mean intraepithelial lymphocyte count was 61.5 per 100 epithelial cells when 10 random high-power fields were counted in each of the five gastric biopsy pieces. The upper limit of normal for gastric intraepithelial lymphocytes is 4 to 7 per 100 epithelial cells with more than 25 per 100 epithelial cells considered diagnostic of lymphocytic gastritis (19). Di Giacomo et al. (20) found a mean of 40.6 intraepithelial lymphocytes per 100 epithelial cells in children who had a diagnosis of lymphocytic gastritis. No atypical lymphocytes or lymphoepithelial lesions, destruction of crypt epithelium, lymphoid follicles, or other features of mucosal-associated lymphoid tissue lymphoma were identified. Only
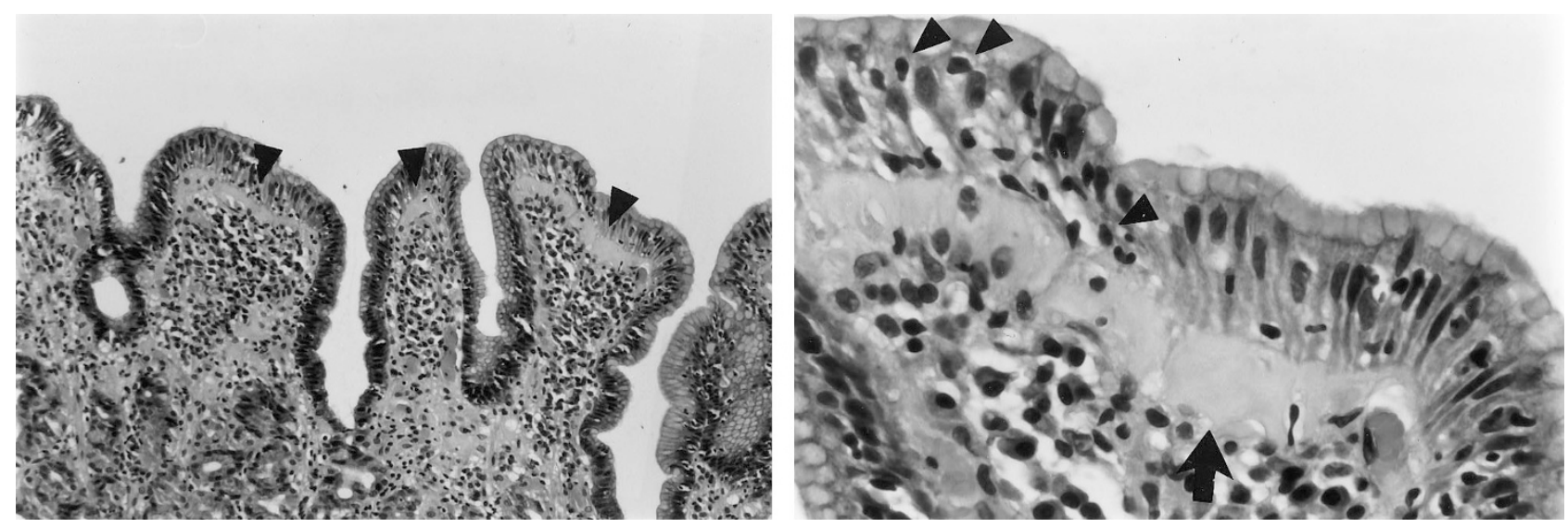

FIGURE 1. Subepithelial collagen deposition in collagenous gastritis localized only to the superficial glandular epithelium (arrowheads) (hematoxylin and eosin $\times 200$ ). Right, gastric antral surface epithelium showing many intraepithelial lymphocytes (arrowheads) and marked thickening of subepithelial collagen (arrow) (hematoxylin and eosin $\times 400$ ). 


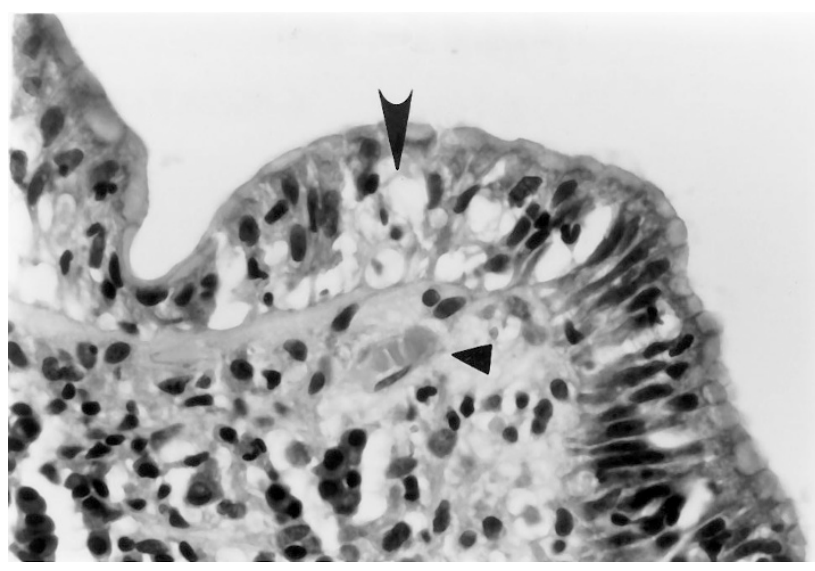

FIGURE 2. Antral mucosa showing subepithelial collagen with entrapped capillary containing red blood cells (arrowhead) and overlying epithelium with intraepithelial lymphocytes, karyorrhectic fragments, and spongiotic epithelial degenerative change (large arrowhead) (hematoxylin and eosin $\times 400$ ).

rare intraepithelial lymphocytes could be found in the control group biopsies and therefore were not quantified

Sections of the duodenum and jejunum showed almost total villous atrophy, crypt hyperplasia with prominent mitotic activity, marked mononuclear cell infiltrates of the lamina propria, and numerous intraepithelial lymphocytes with patchy degeneration of surface enterocytes characteristic of celiac sprue (Fig. 3). Neither neutrophils nor collagen was conspicuous in the small bowel biopsies. Sections of the colon showed a diffuse active colitis pattern of inflammation involving the mucosa from the cecum, transverse, and rectosigmoid colon. The mucosa showed atrophic features with irregular crypt architecture, variable size, and irregular spacing of atrophic glands (Fig. 4). A dense chronic inflammatory infiltrate with basal plasmacytosis occupied the lamina propria continuously in most biopsy fragments. Numerous intraepithelial lymphocytes were identified in the superficial glandu-

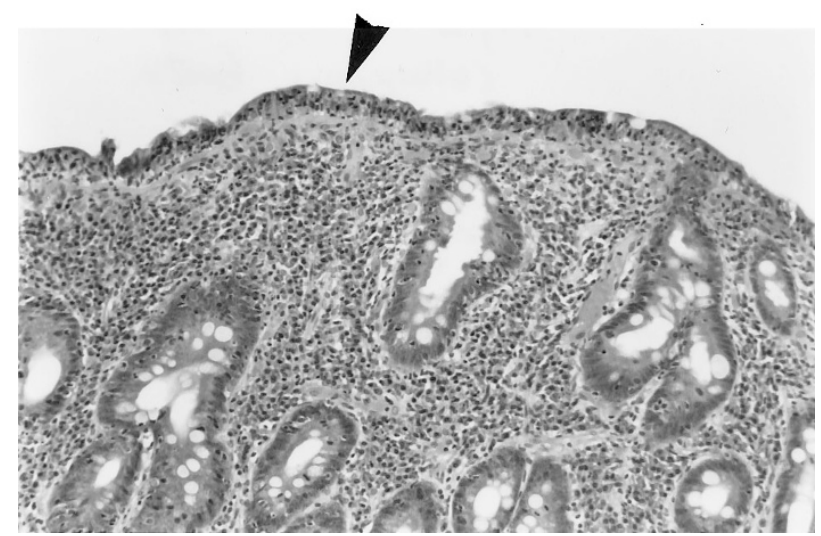

FIGURE 3. Jejunal mucosa with total villous atrophy, intraepithelial lymphocytes (arrowhead), and diffuse plasma cell infiltrates of the lamina propria (hematoxylin and eosin $\times 200$ ).

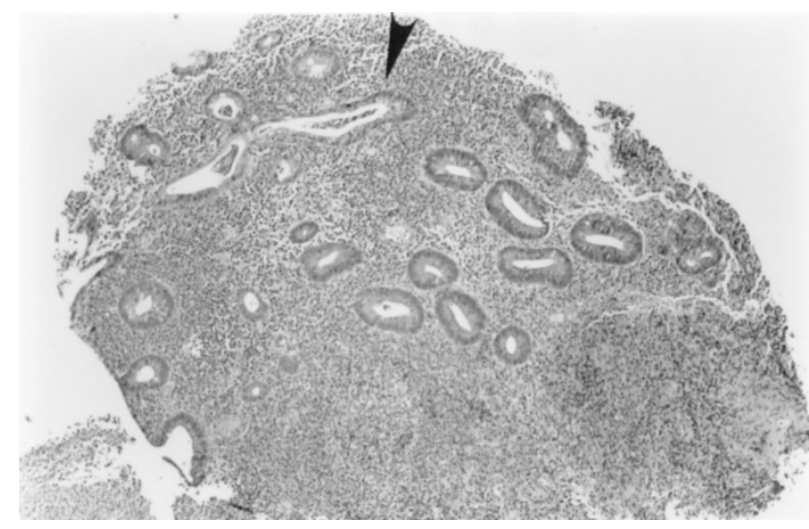

FIGURE 4. Colonic mucosal biopsy with changes consistent with active ulcerative colitis, including irregular glandular morphology, distribution and variable gland size in association with diffuse active colitis, crypt abscesses (arrowhead), and marked lamina propria inflammation (hematoxylin and eosin $\times 40$ ).

lar epithelium. Patchy neutrophilic infiltration of crypt epithelium and crypt abscesses was conspicuous (Fig. 5). No granulomas except for rare mucin granulomas associated with ruptured crypts were identified. Additional findings included Paneth cell metaplasia and a thickened muscularis mucosa in the left colon biopsies. No significant subepithelial collagen deposition was identified in biopsies of the small bowel or colon.

\section{DISCUSSION}

A spectrum of ostensible immune-mediated inflammatory bowel diseases were present in this patient, including collagenous gastritis associated with lymphocytic gastritis, celiac disease, and ulcerative colitis. The histologic findings of intraepithelial lymphocytic infiltrates and epithelial injury throughout the gastric and intestinal biopsy material and the serologic presence of several autoantibodies, including antigliadin, antiendomysial, and pANCA, are unifying features. Recently, reports have shown overlap of both related and seemingly

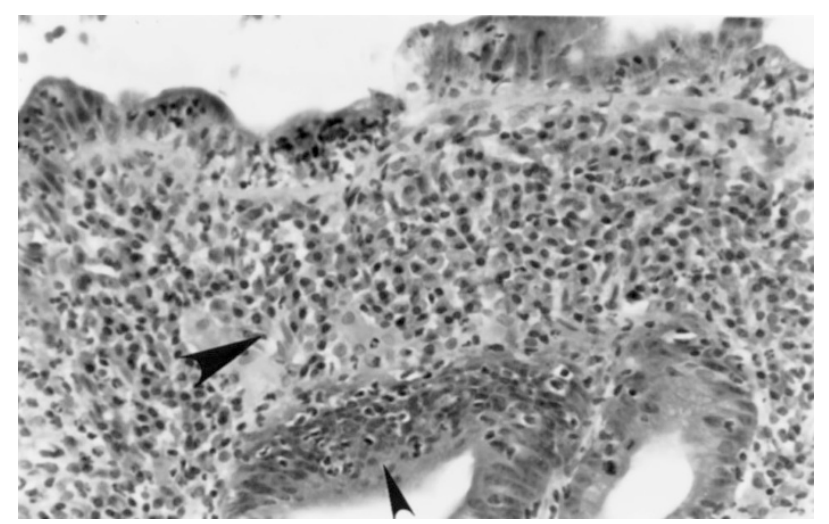

FIGURE 5. Colonic mucosal biopsy with active ulcerative colitis changes including a dense plasmacytic infiltrate (large arrowhead) and active cryptitis (small arrowhead) (hematoxylin and eosin $\times 400$ ). 
unrelated forms of inflammatory bowel disease, including various forms of collagenous and lymphocytic colitis, sprue, Crohn's disease, and ulcerative colitis (17, 21-25). Associated clinical and pathologic features of these chronic inflammatory bowel diseases suggest overlapping causes or a similar pathogenesis. Serum autoantibodies and histocompatibility locus antigens are described in cases of ulcerative colitis, collagenous and lymphocytic colitis, celiac sprue, and lymphocytic gastritis.

Collagenous gastritis seems to be a very rare or underrecognized entity; only four other cases have been reported since 1989. A summary of the clinical presentation and pathologic findings of these cases is presented in Table 2. All reported cases have shown a subepithelial collagen layer significantly thickened in a range of 20 to 30 times that of normal mucosa.

The mechanism of collagen deposition in patients who have collagenous gastritis is unknown. One postulated mechanism of collagen deposition in collagenous colitis is that the collagenous band represents a sequel to inflammation and mucosal injury. Deposition of type III collagen, a repair-type collagen produced by subepithelial fibroblasts, has been demonstrated in collagenous colitis (26-28). Collagen deposition in collagenous gastritis may have a similar pathogenesis considering the close morphologic similarities to collagenous colitis. However, if the mechanism of collagen deposition is simply reparative and related to mucosal injury, then why is some degree of collagen deposition not described in reactive gastropathies, nonspecific gastritis, $H$. pylori gastritis, or other forms of gastric mucosal insult? Undoubtedly, the mechanism is more complex and probably involves immunemediated phenomenon related to the intraepithelial T-lymphocyte infiltrates, epithelial injury, and antibody production.

No reports of collagenous gastritis have appeared in the pathology literature, and no detailed pathologic definition has been elaborated. With the use of morphometric comparison to normal and "gastritis" mucosa, it is a reasonable assertion that subepithelial collagen deposition exceeding $10 \mu$, analogous to collagenous colitis criterion, can confidently identify collagenous gastritis. We are aware of no other condition in which excessive subepithelial collagen in a bandlike distribution has been described. Summary data of the five reported

TABLE 2. Summary of Collagenous Gastritis Case Reports

\begin{tabular}{|c|c|c|c|c|c|}
\hline Case Report & Current Report & Grossman 1996 (15) & Stolte $1990(16)$ & Colletti 1989 (14) & Borchard 1989 (13) \\
\hline Age & 57 & 35 & 75 & 15 & 67 \\
\hline Sex & Male & Female & Female & Female & Female \\
\hline $\begin{array}{l}\text { Clinical } \\
\text { presentation }\end{array}$ & $\begin{array}{l}\text { Diarrhea, rectal } \\
\text { bleeding, } \\
\text { malabsorption }\end{array}$ & $\begin{array}{l}\text { Abdominal distension, } \\
\text { watery diarrhea }\end{array}$ & $\begin{array}{l}\text { Watery } \\
\text { diarrhea for } \\
6 \text { mo }\end{array}$ & $\begin{array}{l}\text { Intermittent } \\
\text { gastric pain for } \\
1 \mathrm{y}\end{array}$ & $\begin{array}{l}\text { Watery diarrhea } \\
\text { for } 2 \mathrm{y}\end{array}$ \\
\hline Endoscopy & $\begin{array}{l}\text { Gastric } \\
\text { erythema, } \\
\text { duodenal } \\
\text { atrophy, } \\
\text { rectosigmoid } \\
\text { erythema } \\
\text { and exudate }\end{array}$ & $\begin{array}{l}\text { Diffuse gastric edema, } \\
\text { nodularity }\end{array}$ & Not reported & $\begin{array}{l}\text { Erythema, } \\
\text { nodularity, } \\
\text { hemorrhagic } \\
\text { mucosa }\end{array}$ & Normal endoscopy \\
\hline Histology & $\begin{array}{l}\text { Diffuse chronic } \\
\text { gastritis }\end{array}$ & $\begin{array}{c}\text { Patchy surface damage, } \\
\text { nonspecific gastritis }\end{array}$ & $\begin{array}{l}\text { Active chronic } \\
\text { gastritis }\end{array}$ & $\begin{array}{l}\text { Patchy, } \\
\text { superficial } \\
\text { active chronic } \\
\text { gastritis }\end{array}$ & $\begin{array}{l}\text { Active chronic } \\
\text { gastritis }\end{array}$ \\
\hline Collagen & $\begin{array}{l}\text { Antrum surface } \\
\text { epithelium, } \\
\text { mean } 27 \mu\end{array}$ & $\begin{array}{l}\text { Surface epithelium avg. } \\
\qquad 20-30 \mu\end{array}$ & $\begin{array}{l}\text { Antrum, body } \\
\text { surface } \\
\text { epithelium } \\
30-60 \mu\end{array}$ & $\begin{array}{l}\text { Antrum surface } \\
\text { epithelium } \\
\text { avg. } \\
25-30 \mu\end{array}$ & $\begin{array}{l}\text { Location not } \\
\text { specified } \\
60 \mu\end{array}$ \\
\hline $\begin{array}{l}\text { Lymphocytic } \\
\text { gastritis }\end{array}$ & Yes & Not reported & Not reported & Not reported & Not reported \\
\hline $\begin{array}{l}\text { Significant } \\
\text { labs }\end{array}$ & $\begin{array}{l}\text { IgA, gliadin, } \\
\text { endomysial } \\
\text { titers } \\
\text { elevated, } \\
\text { pANCA }\end{array}$ & Antigliadin G,A negative & Not reported & $\begin{array}{l}\text { IgG,A,M,E, ANA, } \\
\text { parietal cell } \\
\text { and IF } \\
\text { negative }\end{array}$ & $\begin{array}{l}\text { No serum } \\
\text { autoantibodies }\end{array}$ \\
\hline $\begin{array}{c}\text { Associated } \\
\text { diseases }\end{array}$ & $\begin{array}{l}\text { Celiac sprue, } \\
\text { mucosal } \\
\text { ulcerative } \\
\text { colitis }\end{array}$ & Lymphocytic colitis & $\begin{array}{l}\text { Collagenous } \\
\text { colitis, sprue }\end{array}$ & $\begin{array}{l}\text { Normal } \\
\text { esophageal, } \\
\text { duodenal, } \\
\text { colon biopsies }\end{array}$ & $\begin{array}{l}\text { Collagenous sprue, } \\
\text { collagenous } \\
\text { colitis }\end{array}$ \\
\hline Treatment & $\begin{array}{l}\text { Asacol, gluten } \\
\text { restriction }\end{array}$ & $\begin{array}{l}\text { Sucralfate, famotene, } \\
\text { sulfasalazine }\end{array}$ & Not given & $\begin{array}{l}\text { Ranitidine, } \\
\text { sucralfate, } \\
\text { furazolidane }\end{array}$ & Loperamide \\
\hline Course & $\begin{array}{l}\text { Resolution of } \\
\text { diarrhea and } \\
\text { gastrointestinal } \\
\text { bleeding }\end{array}$ & $\begin{array}{l}\text { Resolution of diarrhea } \\
\text { only }\end{array}$ & Not given & $\begin{array}{l}\text { No clinical/ } \\
\text { pathologic } \\
\text { resolution }\end{array}$ & $\begin{array}{l}\text { Residual gastric } \\
\text { collagen at } \\
\text { rebiopsy }\end{array}$ \\
\hline
\end{tabular}


cases of collagenous gastritis show a mean subepithelial collagen thickness of $36.9 \mu$ (Table 2). In our control group data, the mean thickness of collagen, even in severe active chronic gastritis, rarely exceeded $3 \mu$. We propose that the diagnosis of collagenous gastritis also requires biopsy evidence of gastritis, epithelial injury, and intraepithelial lymphocytes, analogous to collagenous colitis, although other case reports have not entirely documented some of these features. It is interesting that three of the five reported cases had coexisting sprue, three had collagenous or lymphocytic colitis, four were female, and three presented with watery diarrhea. This apparently common association with a similar clinical syndrome and morphologically similar lesions in other parts of the gastrointestinal tract empirically suggests overlapping pathologic features. Appropriate therapy for collagenous gastritis has not been established, and resolution with specific therapy has not be documented.

Probably an insufficient number of cases of collagenous gastritis have been reported to extrapolate consistent clinical, laboratory, endoscopic, and pathologic findings. However, even with the few reported cases, the dramatically thickened gastric subepithelial collagen does seem to be a morphologically distinct and diagnosable pathologic finding with intriguing histologic and clinical similarities to the other "collagenous enterocolitides."

\section{REFERENCES}

1. Lindstrom CG. Collagenous colitis with watery diarrhea-a new entity? Pathol Eur 1976;11:87-9.

2. Gran JT, Husby G. Joint manifestations in gastrointestinal diseases: Whipples disease, enteric infections, intestinal bypass operations, gluten sensitive enteropathy, pseudomembranous colitis and collagenous colitis. Dig Dis 1992;10(5): 295-312.

3. Jesserun J, Yardley JH, Giardiello FM, Hamilton SR, Bayless TH. Chronic colitis with thickening of the subepithelial collagen layer (collagenous colitis): histopathologic findings in 15 patients. Hum Pathol 1987;18:839-48.

4. Roubenoff R, Ratain J, Giardiello F, Hochberg M, Bias W, Lazenby A, et al. Collagenous colitis, enteropathic arthritis and autoimmune diseases: results of a patient survey. J Rheumatol 1989;16:1229-32.

5. Snook J. Are the inflammatory bowel diseases autoimmune disorders? Gut 1990;31:961-3.

6. Van Tilburg AJP, Lam HGT, Sedlenrijk CA, Stel HV, Blok P, Dekter W, et al. Familial occurrence of collagenous colitis. A report of two families. J Clin Gastroenterol 1990;12:279-85.

7. Anderson T, Tvede M, Franzman MB. Collagenous colitis: are bacterial cytotoxins responsible? Am J Gastroenterol 1993;88(3):375-7.
8. Giardiello FM, Hansen F, Lazenby AJ, Hillman DB, Milligan FD, Bayless TM, et al. Collagenous colitis in setting of nonsteroidal anti-inflammatory drugs and antibiotics. Dig Dis Sci 1990;35(2):257-60.

9. Jarnerot G, Tyck C, Bohr J, Erikson S. Collagenous colitis and fecal stream diversion. Gastroenterology 1995;109:449-55.

10. Ridell RH, Tanaka M, Mazzolini G. Non-steroidal antiinflammatory drugs as a possible cause of collagenous colitis: a case control study. Gut 1992;33:683-6.

11. Weinstein WM, Saunders DR, Tytgat GN, Rubin CE. Collagenous sprue-an unrecognized type of malabsorption. N Engl J Med 1970;283:1297-301.

12. Bossart R, Henry K, Booth CC, Doe WF. Subepithelial collagen in intestinal malabsorption. Gut 1975;16:18-22.

13. Borchard F, Niederau C. Kollagene gastroduodenitis. Dtsch Med Wschr 1989;114:1345.

14. Colletti RB, Trainer T. Collagenous gastritis. Gastroenterology 1989;97:1552-5.

15. Grossman GM, Myers S, Harpaz N. Collagenous gastritis associated with lymphocytic colitis. J Clin Gastroenterol 1996;22(2):134-7.

16. Stolte M, Ritter M, Borchard F, Koch-Scherner G. Collagenous gastroduodenitis on collagenous colitis. Endoscopy 1990;22:186-7.

17. Bogomoletz WV. Collagenous, microscopic and lymphocytic colitis. An evolving concept. Virchows Arch 1994;424:573-9.

18. Lee E, Schiller LR, Vendrell D, Santa Ana C, Fordtran JS. Subepithelial collagen table thickness in colon specimens from patients with microscopic colitis and collagenous colitis. Gastroenterology 1992;103:1790-6.

19. Haot J, Hamichi L, Wallez I, Manguet P. Lymphocytic gastritis: a newly described entity. A retrospective endoscopic and histologic study. Gut 1988;29(9):1258-64.

20. De Giacomo C, Giannati A, Negrini R, Perotti P, Bawa P, Maggiore G, et al. Lymphocytic gastritis, a positive relationship with celiac disease. J Pediatr 1994;124:57-62.

21. Armes J, Gee DC, Macrae FA, Schroeder W, Bhathal PS. Collagenous colitis: jejunal and colorectal pathology. J Clin Pathol 1992;45:784-7.

22. Chandratre S, Bramble ME, Cooke WM, Jones RA. Simultaneous occurrence of collagenous colitis and Crohn's disease. Digestion 1987;36(1):55-60.

23. Eckstein RP, Dowsett JF, Riley JW. Collagenous enterocolitis: a case of collagenous colitis with involvement of the small intestine. Am J Gastroenterol 1988;83:767-71.

24. Giardiello F, Jackson FW, Lazenby AJ. Metachronous occurrence of collagenous colitis and ulcerative colitis. Gut 1991; 32:447-9.

25. Hamilton I, Sanders S, Hopwood D, Bouchier I. A case report. Collagenous colitis associated with small intestinal villous atrophy. Gut 1986;27:1394-8.

26. Catchpole HR. Connective tissue, basement membrane, extracellular matrix. Pathobiol Annu 1982;12:1-33.

27. Flejou JF, Grimaud JA, Molas G, Baviera E, Potet F. Collagenous colitis. Ultrastructural study and collagen immunotyping of four cases. Arch Pathol Lab Med 1984;108:977-82.

28. Jessurun J, Yardley JH, Giardiello FM, Hamilton SR, Bayless TM. Chronic colitis with thickening of the subepithelial collagen layer (collagenous colitis): histopathologic findings in 15 patients. Hum Pathol 1987;18:839-48. 